\title{
Critical Raw Materials Recovery through Bio/Hydrometallurgy from Secondary Resources
}

\author{
Manivannan Sethurajan ${ }^{1}$ and Eric D. van Hullebusch ${ }^{1,2, *(1)}$ \\ 1 Department of Environmental Engineering and Water Technology, IHE Delft Institute for Water Education, \\ Westvest 7, 2611 AX Delft, The Netherlands; biotek_mani@yahoo.co.in \\ 2 Université de Paris, Institut de physique du globe de Paris, CNRS, F-75005 Paris, France \\ * Correspondence: vanhullebusch@ipgp.fr; Tel.: +33-1-83-95-78-36
}

Received: 28 October 2019; Accepted: 14 November 2019; Published: 16 November 2019

\section{Introduction and Scope}

Demand for critical raw materials (CRMs) to be used in consumer products is growing rapidly. However, in the past couple of decades, the world's high-grade metal reserves have been depleted considerably. As a result, alternative resources are currently being explored for metal extraction. In this regard, secondary resources have received considerable attention as they contain a considerable amount of valuable metals. Conventional pyrometallurgical processes are not really of use for resource recovery from secondary resources because of their high energy and cost requirements.

On the other hand, bio/hydrometallurgy is a fast developing, eco-friendly, and cost-effective technology for the extraction of base and precious metals and rare earth elements (REE). Hydrometallurgy consists of leaching and recovery unit operations. Leaching is the solubilization of metals from a solid phase using chemicals or biological agents, whereas recovery is the extraction of metals from polymetallic leachate using physicochemical processes, electrowinning, or biological processes [1]. Bio/hydrometallurgy can be successfully applied not only to a variety of mineral ores such as high grade, low grade, and lean grade ores, but also to secondary resources (such as slags, sludges, red mud, dusts, fly and bottom ashes, and electronic wastes) [2].

\section{Contribution to the Special Issue}

Researchers around the globe investigating the bio and hydrometallurgy of critical, precious, and rare earth elements have been invited to submit research papers so that readers can recognize the common points between them. Among the submitted manuscripts, six papers have been published in the issue.

\subsection{CRMs from Waste Electrical and Electronic Equipment (WEEE)}

Nowadays, recovery of CRMs from waste electrical and electronic equipment (WEEE) is a top priority even in developed countries. These WEEE such as printed circuit boards (PCB), spent liquid crystal displays (LCDs) and light emitting diodes (LEDs), are fast generating waste groups and they contain several CRMs such as Ga, In, W, Nd, Pd, Ta, and other Platinum Group Element (PGE), REE, along with base and heavy metals. Articles that deal with metal recovery from WEEE have been considered for this special issue.

Chen et al. [3] reported the recycling of gallium nitride $(\mathrm{GaN})$ from spent LEDs using pressurized acidic leaching. More than $98 \%$ of Ga can be leached from spent LEDs under optimum conditions (i.e., $0.25 \mathrm{~mol} \cdot \mathrm{L}^{-1}$ of $\mathrm{HCl}$ with a liquid-solid ratio of $30 \mathrm{~mL} \cdot \mathrm{g}^{-1}$ at $200{ }^{\circ} \mathrm{C}(15 \mathrm{~atm})$ ) within $3 \mathrm{~h} \mathrm{[3]}$. Sethurajan et al. [4] investigated the leaching and selective recovery of $\mathrm{Cu}$ (as $\mathrm{Cu}$ sulfide) from waste PCBs. It was reported that more than $98 \%$ of $\mathrm{Cu}$ can be leached under optimum conditions (ferric 
sulfate concentration $(100 \mathrm{mM})$, agitation speed $(300 \mathrm{rpm})$, temperature $\left(20^{\circ} \mathrm{C}\right)$, and solid-to-liquid ratio $\left.\left(10 \mathrm{~g} \cdot \mathrm{L}^{-1}\right)\right)$, and more than $95 \%$ of $\mathrm{Cu}$ can be selectively recovered as $\mathrm{Cu}$ sulfide from the poly metallic leachate by selective metal sulfide precipitation technique.

\subsection{CRMs from Industrial Solid Wastes and Acid Mine Drainage}

Metallurgical wastes from metallurgical industries such as slags, dross, spent catalysts, and sludges contain economically significant levels of precious metals and REE. Acid mine drainage (AMD) also contains economically significant levels of toxic elements and high value metals. Articles focusing on the recovery of these metals from metal bearing wastes materials have also been included in this special issue.

Drzazga et al. [5] investigated and reported the leaching of CRMs such as In and Ge from Polish Zn dross using sulfuric and oxalic acids. It was observed that more than $80 \%$ of In and Ge can be leached using sulfuric acid at high temperature $\left(80^{\circ} \mathrm{C}\right)$, while the leaching by oxalic acid was comparatively less than sulfuric acid leaching. Ding et al. [6] used response surface methodology (Box-Behnken experimental design) to optimize the parameters that could influence the leaching of $\mathrm{Pt}$ from the spent catalysts, and reported that more than $98 \%$ of $\mathrm{Pt}$ can be leached under optimum conditions ( $\mathrm{HCl} 1.45 \mathrm{~mol} \cdot \mathrm{L}^{-1}, \mathrm{NaCl} 4.55 \mathrm{~mol} \cdot \mathrm{L}^{-1}, 10 \% \mathrm{H}_{2} \mathrm{O}_{2} / \mathrm{spent}$ catalysts of $0.66 \mathrm{~mL}^{-1}$, and $\mathrm{S} / \mathrm{L}$ ratio $\left.1: 4.85\right)$. Silva et al. [7] studied and reported the recovery of $\mathrm{Cu}$ (as covellite) from acid mine drainage using sulfide precipitation technique. Biogenic sulfide (produced by sulfate reducing bacteria) was used to precipitate soluble $\mathrm{Cu}$ in AMD to insoluble $\mathrm{CuS}$. It should be noted that the precipitates formed after $96 \mathrm{~h}$ exposure had better ordination than the ones precipitated after $48 \mathrm{~h}$ exposure.

\subsection{CRMs from Low Grade Ores}

A publication dealing with biotechnological innovations in extractive metallurgy such as the use of microorganisms for the leaching and recovery of metals (i.e., biohydrometallurgy) from primary ores and secondary resources has also been presented in this special issue. Nascimento et al. [8] proposed the use of Acidithiobacillus ferrooxidans in column and stirred tank reactors for bioleaching of copper from a mineral sulfide (mostly chalcopyrite) of the Brazilian Amazon region. After 47 days, the column's copper bioleaching efficiency was $1 \%$ and $0.95 \%$ for $2.00 / 4.75 \mathrm{~mm}$ sulfide ore, respectively, whereas the stirred reactors bioleaching displayed better results with $4 \% \mathrm{Cu}$ leaching for the sulfide ore.

\section{Conclusions}

The Special Issue, "Critical Raw Materials Recovery through Bio/Hydrometallurgy from Secondary Resources" deals with research articles covering advanced approaches to bio and hydrometallurgy of critical raw materials. The guest editors believe that this collection of papers may be useful to people who are actively involved (directly or indirectly) in this field. This special issue was successful already, but if the articles in this issue can inspire and invite more research studies, debates, and discussion in the field, that will make it even more special.

Acknowledgments: The guest editors would like to thank all who have contributed directly and indirectly for the successful development of this Special Issue. The guest editors thank all the scholars and authors who submitted their manuscripts and were willing to publish their research activities in this Special issue. Special mention and sincere thanks to the reviewers who agreed to review the articles and provide feedback to improve the quality of the manuscripts. Credits should also be given to the editors and to Managing Editor Natalie Sun and also all the staff of the Metals Editorial Office for their contribution and support in the publication process of this issue.

Conflicts of Interest: The authors declare no conflicts of interest. 


\section{References}

1. Sethurajan, M.; van Hullebusch, E.D.; Fontana, D.; Akcil, A.; Deveci, H.; Batinic, B.; Leal, J.P.; Gasche, T.A.; Kucuker, M.A.; Kuchta, K.; et al. Recent advances on hydrometallurgical recovery of critical and precious elements from end of life electronic wastes-a review. Crit. Rev. Environ. Sci. Technol. 2019, 49, 212-275. [CrossRef]

2. Sethurajan, M.; van Hullebusch, E.D.; Nancharaiah, Y.V. Biotechnology in the management and resource recovery from metal bearing solid wastes: Recent advances. J. Environ. Manag. 2018, 211, 138-153. [CrossRef] [PubMed]

3. Chen, W.-S.; Hsu, L.-L.; Wang, L.-P. Recycling the GaN Waste from LED Industry by Pressurized Leaching Method. Metals 2018, 8, 861. [CrossRef]

4. Sethurajan, M.; van Hullebusch, E.D. Leaching and Selective Recovery of $\mathrm{Cu}$ from Printed Circuit Boards. Metals 2019, 9, 1034. [CrossRef]

5. Drzazga, M.; Prajsnar, R.; Chmielarz, A.; Benke, G.; Leszczyńska-Sejda, K.; Ciszewski, M.; Bilewska, K.; Krawiec, G. Germanium and Indium Recovery from Zinc Metallurgy by-Products-Dross Leaching in Sulphuric and Oxalic Acids. Metals 2018, 8, 1041. [CrossRef]

6. Ding, Y.; Zheng, H.; Li, J.; Zhang, S.; Liu, B.; Ekberg, C.; Jian, Z. Recovery of Platinum from Spent Petroleum Catalysts: Optimization Using Response Surface Methodology. Metals 2019, 9, 354. [CrossRef]

7. Silva, P.M.P.; Lucheta, A.R.; Bitencourt, J.A.P.; Carmo, A.L.V.; Cuevas, I.P.Ñ.; Siqueira, J.O.; Oliveira, G.C.; Alves, J.O. Covellite (CuS) Production from a Real Acid Mine Drainage Treated with Biogenic $\mathrm{H}_{2} \mathrm{~S}$. Metals 2019, 9, 206. [CrossRef]

8. Nascimento, D.N.O.; Lucheta, A.R.; Palmieri, M.C.; Carmo, A.L.V.; Silva, P.M.P.; Ferreira, R.V.P.; Junca, E.; Grillo, F.F.; Alves, J.O. Bioleaching for Copper Extraction of Marginal Ores from the Brazilian Amazon Region. Metals 2019, 9, 81. [CrossRef]

(C) 2019 by the authors. Licensee MDPI, Basel, Switzerland. This article is an open access article distributed under the terms and conditions of the Creative Commons Attribution (CC BY) license (http://creativecommons.org/licenses/by/4.0/). 